\title{
Sexo y destrucción en el surrealismo español: Buñuel, Dalí y Lorca según la pulsión de muerte
}

\author{
María del Carmen Molina BAREA \\ Universidad de Córdoba \\ Departamento de Ciencias Sociales y Humanidades. \\ mcpalladio@hotmail.com
}

Enviado: $10-05-2012$

Revisado: 15-10-2012

\section{RESUMEN}

El presente trabajo adopta como punto de partida las teorías sobre la pulsión de muerte que, bajo diferentes perspectivas, alumbraron Sigmund Freud y Sabina Spielrein, considerada la primera mujer en la historia del psicoanálisis. Teniendo por referencia dicho marco conceptual, el objetivo de estas páginas consistirá en analizar aspectos de la vida y obra de tres destacadas figuras en la historia del arte contemporáneo español, íntimamente relacionadas entre sí por una fructífera amistad de juventud: se trata de Luis Buñuel, Salvador Dalí y Federico García Lorca. Lo que se pretende es, pues, un acercamiento al universo de estos tres creadores teniendo por horizonte las teorizaciones que en torno al fenómeno de la sexualidad y la muerte gestaron Freud y Spielrein; observando en qué medida y según qué particularidades es posible hablar de influencias o conexiones entre dichas teorías y los referidos artistas.

Palabras clave: Pulsión de muerte, Eros, Thánatos, Freud, Sabina Spielrein, sado-masoquismo, fetichismo, narcisismo, Buñuel, Dalí, Lorca.

\section{Sex and Destruction in Spanish Surrealism: Buñuel, Dalí and Lorca According to the Death Drive}

\begin{abstract}
The present paper takes as starting point the different theories about the Death drive conceived by Sigmund Freud and Sabina Spielrein -who is considered by many to be the first woman in the history of psychoanalysis. Taking this context as our main conceptual basis, the objective pursued consists of analyzing several aspects of the life and work of three important figures of Spanish Contemporary Art History, closely linked by a productive friendship in their youth. We are referring to Luis Buñuel, Salvador Dalí and Federico García Lorca. Consequently, the main aim is to study the creative universe of these three artists according to the fundamental theories created by Freud and Spielrein in relation to the phenomenon of sexuality and death, thus considering the extent to which we are able to speak of influences or connections between these theories and the aforementioned artists.
\end{abstract}

Key words: Death Drive, Eros, Thánatos, Freud, Sabina Spielrein, Sadomasochism, Fetishism, Narcissism, Buñuel, Dalí, Lorca.

Sumario: 1. Introducción: sexo y muerte en la confluencia de surrealismo y psicoanálisis. 2. Teorías psicoanalíticas sobre la pulsión de muerte. Entre Freud y Sabina Spielrein. 3. El diálogo de Eros y Thánatos en la obra de Luis Buñuel: sado-masoquismo, fetichismo y destrucción. 4. Dalí: de la mantis religiosa a la metamorfosis de Narciso. 5. Federico García Lorca o el miedo (amor) a la muerte. 6. Ideas conclusivas. 7. Bibliografía. 8. Índice de ilustraciones. 


\section{Introducción: sexo y muerte en la confluencia de surrealismo y psicoanálisis}

Es sobradamente conocida la vinculación que desde su nacimiento establece el surrealismo con el psicoanálisis, disciplina ésta que se erige en un elemento crucial para entender la constitución del movimiento surrealista y el espíritu que lo anima. Aspectos como el potencial liberador del subconsciente, del instinto y de los sueños, así como la lúdica subversión del mundo onírico, la fantasía revolucionaria de la perversión y nuevas formas de comprensión de lo sexual hicieron que los jóvenes artistas contextualizados en el ambiente surrealista abrazaran con devoción la obra freudiana. La razón fundamental que motiva dicha fascinación podemos hallarla en el propio carácter del movimiento surrealista, ya que, como explica Luis Buñuel en sus memorias:

'Aquella moral surrealista, agresiva y clarividente solía ser contraria a la moral corriente, que nos parecía abominable, pues nosotros rechazábamos en bloque los valores tradicionales. Nuestra moral se apoyaba en otros criterios, exaltaba la pasión, la mixtificación, el insulto, la risa malévola, la atracción de las simas.' ${ }^{1}$

Antes incluso de fundarse el grupo como tal, el que fuera su padre y caudillo, André Breton, ya leía con apasionamiento a Freud en los días en que cumplía servicio en manicomios militares durante la Primera Guerra Mundial. Su interés por el maestro del psicoanálisis le llevará incluso a hacerle una visita en el año 1921. Desde entonces, surrealismo y psicoanálisis serán dos términos, aún más, dos entidades ontológicas, imposibles de separar. Sin embargo, resulta interesante remarcar que Freud nunca dedicó especial atención al surrealismo; a esos jóvenes que lo habían adoptado como "santo patrón", y cuyo estridente comportamiento y provocadora estética le parecían dentro del campo clínico de la locura ("locos integrales", como les califica en su diario tras el encuentro con Salvador Dalí en Londres en 1938). Esto que pudiera parecer una contradicción en las íntimas conexiones que hemos señalado entre surrealismo y psicoanálisis no es, en realidad, tal incongruencia. Se trata más bien de un síntoma que pone en evidencia la particularidad en virtud de la cual los surrealistas adoptaron las teorías freudianas, de manera que ni el propio Freud supo comprender el modo y grado en que estos artistas se habían aproximado a su pensamiento:

'En su breve correspondencia con André Breton, [Freud] escribió: “A pesar de que recibo numerosos testimonios del interés que usted y sus amigos muestran hacia mis investigaciones, yo mismo no estoy capacitado para entender qué es lo que quiere el surrealismo. Quizá no estoy de ningún modo hecho para comprenderlo, yo, que me encuentro tan alejado del arte".,2

Los surrealistas se acercaron a la obra de Freud para entresacar aquellos aspectos que despertaron su interés; para apropiarse de ellos y, en cierto modo, reinterpretarlos, empleándolos libremente y aplicándolos en sus creaciones a través de los métodos

\footnotetext{
1 BUÑUEL, Luis, Mi último suspiro, Barcelona, Plaza \& Janés, 1982, p. 106.

2 IRIBAS RUDÍN, Ana, "Salvador Dalí desde el psicoanálisis", en Arte, individuo y sociedad, vol. 16, 2006, p. 28.
} 
artísticos y procedimientos estéticos determinados por el grupo (escritura automática, imaginación poética, humor onírico, etc.). Podría decirse que las obras nacidas del surrealismo están plagadas de elementos freudianos al margen de Freud... Lo cierto es que los surrealistas supieron ver en la miscelánea psicoanalítica una cantera de elementos, imágenes, teorías, comportamientos e interpretaciones que respondían a sus gustos e inclinaciones y que encajaban con los objetivos pretendidos por el grupo. En otras palabras, el surrealismo halló en la obra de Freud un novedoso material, potencialmente subversivo y liberador, que casaba a la perfección con sus ideales de ruptura y revolución. Por tanto, queda fuera de toda duda la determinante influencia que el psicoanálisis ejerció en este movimiento de vanguardia nacido en París en la década de los 20, desde sus planteamientos iniciales hasta las últimas cristalizaciones de su estética, salpicando todos los resortes de su imaginario iconográfico y conceptual.

Entre los temas que pueblan dicho universo ideográfico, surcado por la inconfundible huella del psicoanálisis, cabe destacar uno en particular: el diálogo, destructor y a la vez creador, entre sexualidad y muerte. Semejante motivo se convierte en una sutil obsesión entre los surrealistas en general; aunque es entre sus representantes españoles donde la influencia del tema se aprecia con mayor calado, ya que los surrealistas franceses se centran mucho más en la faceta arrolladora de la pasión y en el poder liberador del amor ${ }^{3}$, del amour fou, mientras que los surrealistas españoles se verán siempre lastrados por cierto sentido de la angustia y del fatalismo unido al sexo. En estas páginas, hablar de surrealistas españoles equivaldrá, en concreto, a referirse a los nombres de Luis Buñuel y Salvador Dalí, si bien contemplaremos por extensión el de Federico García Lorca, cuya ambigua y discutida inclusión en las filas surrealistas tanto ha dado que hablar $-\mathrm{y}$ escribir- ${ }^{4}$, pero que aquí nos interesa en la medida en que forma parte, como pieza fundamental de un engranaje mayor, de las relaciones artísticas y personales que se gestaron entre el cineasta aragonés y el pintor catalán en los años compartidos en la Residencia de Estudiantes de Madrid; fechas en las que, casualmente, se entregaron con pasión a las lecturas freudianas.

Este tema del sexo y la muerte, o mejor, de la muerte en el sexo, pulula constantemente por la obra de Buñuel, Dalí y Lorca, disfrazado de distintas excusas argumentales, icónicas o expresivas. Si observamos con atención, apreciaremos que actúa como una especie de dramático leit motiv que discurre subterráneo y que de vez en cuando, con reiterada frecuencia, supura en la superficie encontrando vía de canalización en la variada apariencia de distintos medios y temas, ya sea a través de determinadas escenas del cine buñueliano, de seleccionados lienzos de la producción daliniana, o de ciertos títulos del repertorio lorquiano. De hecho, como veremos, el hermanamiento sexo-muerte está siempre presente en estos artistas, y se impone con personalidad propia en sus experiencias y creaciones; de forma que incluso podría ser entendido como un nexo, más o menos inconsciente, que en su día propiciara o

3 Tómese como ejemplo el poema "La muerte rosa" (del libro recopilatorio Poemas (1948)) de André Breton, o uno de los últimos y más conocidos poemas escritos por Paul Éluard, "La muerte, el amor, la vida", del año 1951.

4 Ver, entre otros: HARETCHE, Estella, "Una cuestión debatida: El surrealismo de Lorca", en Surrealismo: el ojo soluble (J. García Gállego, comp.), Litoral, Torremolinos, 1987, pp. 259-268. 
facilitara esa relación de amistad y de producción artística entre los tres compañeros, especialmente unidos en su etapa "residencial".

No casualmente, la conjunción de sexo y muerte desempeña también un rol protagonista en las teorías psicoanalíticas. En concreto, sus implicaciones son analizadas por Sigmund Freud y expuestas en su ensayo Más allá del principio del placer (1920), en lo que suele denominarse "teoría de la pulsión de muerte". Sin embargo, y aún siendo el más conocido, Freud no es el único que desarrolla este tema; con anterioridad a él la joven psicoanalista Sabina Spielrein había investigado en profundidad el maridaje sexo-muerte en su tesis doctoral, Sobre el contenido psicológico de un caso de esquizofrenia (demencia precoz), publicada en 1911. Así mismo, al año siguiente, Spielrein publicaba un artículo que ahondaba en la cuestión: La destrucción como causa del nacimiento. El caso de Sabina Spielrein, por lo desconocido y sugerente de su figura, reviste, además, un especial interés: Judía de origen ruso, Spielrein entra en el ambiente psicoanalítico primero como paciente; a los diecinueve años es ingresada en Burghölzli, Zúrich, bajo la tutela de Carl Gustav Jung, quien la curó de una fuerte crisis de histeria. Prontamente, Sabina empezó a colaborar con Jung en las investigaciones de éste, y en 1905 se matriculaba en la Facultad de Medicina de Zúrich, ingresando seis años más tarde, con motivo de la publicación de su tesis, en la Asociación Psicoanalítica de Viena. Mujer de gran talento e incansable potencial, destinaría sus esfuerzos futuros a realizar destacadas aportaciones en el ámbito de la psicología infantil.

La carrera profesional de Spielrein se liga, pues, en sus inicios a la línea investigadora de la escuela psicoanalítica de Zúrich, encabezada por C. G. Jung. De hecho, la intervención de Sabina en los hallazgos del psicoanálisis junguiano es crucial, sobre todo en la época en que fue amante de su antiguo doctor, pues se influían mutuamente en sus respectivos trabajos, sobre todo en temas de interés común, caso del wagneriano mito de Sigfrido. Pero no sólo en Jung tendrían eco las ideas de Spielrein; también en Freud, que era directo conocedor de su caso clínico, y que además estaba al tanto de las relaciones de ésta con Jung, así como de los motivos científicos que guiaban sus investigaciones. En este contexto resulta oportuno volver a los descubrimientos pioneros de Spielrein acerca de la pulsión de muerte, y mencionar que Freud cita el trabajo de Sabina en una nota a pie de página en Más allá del principio del placer. No cabe duda de que Freud conocía la obra de Spielrein ${ }^{5}$ y que toma de ella la idea originaria de la pulsión de muerte. ${ }^{6}$ Sin embargo, son sustanciales y significativas las diferencias que los separan. Así lo deja entrever el propio Freud en la referida nota a

\footnotetext{
5 'In fact Spielrein had written to him [Freud] on her theory as early as 1909 stating: "This demonic force, whose very essence is destruction (evil), at the same time is the creative force, since out of the destruction (of two individuals) a new one arises. That is in fact the sexual drive, which is by nature a destructive drive, an exterminating drive for the individual, and for that reason, in my opinion, must overcome such great resistance in everyone".' (SKEA, Brian R., "Sabina Spielrein: out from the shadow of Jung and Freud", en Journal of Analytical Psychology, 2006, vol. 51, p. 544).

6 Jung lo atestigua en una escueta nota a pie de página en su On the psychology of the unconscious, al final del capítulo dedicado a la teoría del Eros: “This idea came originally from my pupil S. Spielrein: cf. 'Die Destruktion als Ursache desWerdens' (1912). This work is mentioned by Freud, who introduces the destructive instinct in Beyond the Pleasure Principle (orig. 1920)".' (Ibid., p. 545).
} 
pie de página. ${ }^{7}$ Considerada una de las primeras mujeres en la historia del psicoanálisis, la figura de Sabina Spielrein ha sido revalorizada en los últimos años y rescatada de la sombra a la que había sido destinada; injusta marginación que ya sufrió parcialmente en vida, incluso por parte de Freud y Jung. ${ }^{8}$

Habiendo situado el escenario contextual y el decorado argumental, intentaremos a continuación proporcionar una visión de la teoría de la pulsión de muerte según Freud y según Spielrein, acusando sus semejanzas pero también sus reveladoras diferencias. Por medio de este análisis, y en base al mismo, se aspira a poder considerar en próximos apartados el diálogo sexo-muerte que preside la vida y obra de Luis Buñuel, Salvador Dalí y Federico García Lorca.

\section{Teorías psicoanalíticas sobre la pulsión de muerte. Entre Freud y Sabina Spielrein}

Es al padre del psicoanálisis a quien debemos la definición de "pulsión" (trieb), término que viene a designar una tendencia psíquica del organismo hacia la satisfacción de excitaciones intrasomáticas en continuo fluir. Siguiendo la especificación que hace Freud, es posible diferenciar dos tipos de pulsiones: pulsión de vida (Eros) y pulsión de muerte (Thánatos). La pulsión de vida está encaminada a la unión y al crecimiento progresivo, a la ligazón. Por el contrario, la pulsión de muerte, en un afán por retornar al reposo del original estado inorgánico del individuo, se manifiesta en la destrucción de lo vivo y en la disolución de conexiones. Ante esta amenaza para sus objetivos, Eros se afana en contrarrestar la acción destructora de Thánatos, y para ello se funde con él, resultando así un cúmulo de fusión pulsional en variada proporción que se canaliza a través de dos vías distintas: por un lado, parte de este conglomerado pulsional es proyectado hacia el exterior en forma de agresividad, mientras que otra parte permanece en el interior del organismo.

Siendo éste el posicionamiento básico de la comprensión freudiana de las pulsiones, es necesario apuntar, como señala Paulina $\mathrm{Corsi}^{9}$, que la teorización que hace Freud de esta materia evoluciona por lo menos a lo largo de tres fases, en un intervalo cronológico que va desde 1905 hasta la definitiva condensación de la teoría en 1920 con el texto Más allá del principio del placer. En la primera etapa, de 1905 a 1914, Freud se refiere a las pulsiones como pulsiones de autoconservación (o pulsiones

\footnotetext{
7 'En un trabajo muy rico en ideas, aunque para mí no del todo transparente, emprende Sabina Spielrein una parte de esta investigación y califica de "destructores" a los componentes sádicos del instinto sexual [...]. (FREUD, Sigmund, Psicología de las masas; Más allá del principio del placer; El porvenir de una ilusión, Biblioteca Freud. Alianza, Madrid, 2003, p. 20).

8 El trabajo de John Kerr, La historia secreta del psicoanálisis. Jung, Freud y Sabina Spielrein, publicado en 1995, de título original A most dangerous method. The story of Jung, Freud and Sabina Spielrein, supuso un primer paso y un aporte de crucial relevancia en esta labor de "re-descubrimiento" de Sabina Spielrein, y sacó a la luz la relación triangular de influencias, afecto y rivalidades que se produjo entre estas figuras clave de la historia del psicoanálisis. Inspirándose en la investigación de Kerr, el director de cine David Cronenberg realiza en el año 2011 la película $A$ dangerous method, interpretando el papel de Sabina Spielrein la actriz británica Keira Knightley.

9 CORSI, Paulina, "Aproximación preliminar al concepto de pulsión de muerte en Freud", en Revista Chilena de Neuro-psiquiatría (versión On-line), vol. 40, nº. 4, 2002, pp. 361-370.
} 
del yo) y pulsiones sexuales. Estas últimas suponen una fuerza turbadora que las pulsiones del yo, velando por su integridad, se encargarán de reprimir. En esta etapa, Freud ya vislumbró componentes agresivos en las pulsiones sexuales, considerando su manifestación activa como dominación masculina, externa o sádica, y su vertiente pasiva como femenina o masoquista. A este bagaje añade Freud sus investigaciones sobre el narcisismo, que efectúa en la segunda etapa, entre 1914 y 1919. En esta fase, Freud localiza dos tipos de energía en las pulsiones sexuales: se trata de la libido del yo y de la libido objetal. La del yo, también llamada libido narcisista, dirige su atención al propio yo, protegiendo la integridad yoica al reprimir la libido que tiende hacia el objeto sexual externo, el cual irrumpe en la tranquilidad del yo como estímulo excitante y en consecuencia, como un displacer que hay que saciar. Esta explicación justificaría los fenómenos sexuales de agresividad contra el objeto sexual externo en los casos de sadismo.

Finalmente, en la tercera etapa, Freud termina por equiparar directamente las fuerzas destructivas con la sexualidad, que llamará, como sabemos, Thánatos, o principio de muerte, también conocido como principio de nirvana, en la medida en que su finalidad es el mantenimiento de la tranquilidad del yo frente a excitaciones. ${ }^{10}$ Por su parte, la pulsión de vida, Eros, se corresponde con el principio del placer, y su objetivo es solventar las excitaciones logrando así el placer necesario a estas demandas del displacer. Por lo tanto, el principio del placer pretenderá el control del principio de nirvana para adecuarlo al principio de realidad, es decir, para acomodarlo a las demandas y necesidades del mundo exterior. Freud lo resume de la siguiente manera:

'El principio del nirvana expresa la tendencia del instinto de muerte; el principio del placer representa la aspiración de la libido; y la modificación de este último principio, el principio de la realidad, corresponde a la influencia del mundo exterior. ${ }^{11}$

De todo esto colegimos que a lo largo de su teorización Freud está esbozando el funcionamiento de la lucha entre la pulsión de muerte y la pulsión de vida, haciendo hincapié en el modo en que se lleva a cabo la represión de la libido. Así, de acuerdo con su formulación y con la triple realidad psíquica freudiana "yo, ello, superyó" 12 , la represión se ejecuta a causa del deseo de Thánatos de autoconservación del yo, el cual podría verse alterado si el ello, en su rol de Eros, se deja libre sin ningún tipo de cortapisa, es decir, si no actúa el superyó por medio del principio de realidad instaurando modos de inhibición del principio del placer para adecuarlo a las demandas de

10 'En otro lugar hemos presentado el principio que rige todos los procesos anímicos como un caso especial de la tendencia a la estabilidad (Fechner), adscribiendo así al aparato anímico la intención de anular la magnitud de excitación a él afluyente o, por lo menos, la de mantenerla en un nivel poco elevado. Barbara Low ha dado a esta supuesta tendencia el nombre de principio del nirvana, denominación que nosotros aceptamos.' (FREUD, Sigmund, Ensayos sobre la vida sexual y la teoría de la neurosis, Biblioteca Freud. Alianza, Madrid, 2003, p. 196).

11 Ibid., p. 197.

12 "El psicoanálisis distingue diferentes campos en la vida psíquica: El "ello", nuestra vida instintiva, el "yo" o la parte organizada de la personalidad y el "superyó", que corresponde aproximadamente a la conciencia. Las exigencias contradictorias de estos campos crean incesantemente problemas [...]. Los síntomas neuróticos y algunos rasgos del carácter son el resultado del fracaso en la resolución de esos problemas.' (WAELDER, Robert, El sexo de Freud, Losada, Madrid, 2005, pp. 33-4). 
la realidad exterior (sociales, morales, culturales...). Pues bien, semejante hipótesis queda en cierto modo empobrecida si se compara con la complejidad de elementos de la propuesta de Sabina Spielrein, quien además, a diferencia de Freud, concibe un paso más en la compresión de la represión de la libido.

En primer lugar, Spielrein otorga mayor densidad a los valores pulsionales: en su opinión, habría que hablar de dos tipos de pulsiones de autoconservación coexistentes en el sujeto; las que son testimonio de los intereses vitales individuales, y las que responden a la voluntad de conservación de la especie. Las primeras se moverían en la esfera del yo, mientras que las segundas, designadas como pulsión sexual, caerían en el campo de dominio del inconsciente; aunque de un inconsciente no propiamente individual, sino entendido más bien como "inconsciente colectivo"; noción vinculada a aspectos biológicos, culturales y raciales, y que Spielrein toma de Jung. En consecuencia, esta última pulsión dirigirá sus objetivos hacia la conservación colectiva, es decir, hacia la perpetuación de la especie; y es precisamente debido a esta finalidad que la pulsión sexual presenta una naturaleza dual, la cual comprende un elemento destructivo y un componente constructivo o de transformación. En otras palabras, en la medida en que la pulsión sexual, cimentada en el inconsciente colectivo, busca la reproducción, se muestra como una fuerza creadora que pretende producir vida, pero que, a la vez, en ese preciso afán de infundir nueva vida, se ve obligada a destruir: dos individuos que se funden en el acto sexual se destruyen a sí mismos para dar así lugar a la posibilidad de engendrar. El fin al que conduce la pulsión sexual implica, por tanto, la disolución del yo, la desintegración de la propia identidad personal; la cual se sacrifica para el ulterior objetivo procreador:

'La sexualidad "quiere" (por metáfora teleológica) tener hijos, y está dispuesta a disolver el yo en el acto de fusión sexual para conseguirlos. [...]. De este modo, desde el punto de vista del yo, la sexualidad entraña una amenaza implícita de disolución. ${ }^{13}$

De este modo, Spielrein halla en la destrucción la causa del nacimiento, como así recogía en su trabajo de semejante título publicado en 1912. En términos psicoanalíticos, esto sería igual que decir que la disolución del yo produce vida. Es decir, que para construir (para conservar la especie, dar vida) se hace necesario destruir, sacrificar el yo. Resulta entonces lógico pensar, como hace Spielrein, que tal fenómeno atemorice al yo, el cual vislumbra en el deseo sexual una amenaza contra su integridad. Dadas las circunstancias, el yo se valdrá de la pulsión de conservación para reprimir el deseo sexual y evitar así su disolución. Ahora bien, el modo en que la pulsión conservadora lleva a cabo dicha represión no se efectúa por medio del principio de realidad, como en el caso de Freud, sino que se materializa, argumenta Spielrein, en la producción de imágenes de muerte y destrucción, que constituyen una efectiva protesta ante el riesgo de desaparición del yo. Es por todo ello que autores como Vallejo Orellana y Sánchez-Barranco Ruiz defienden que, en realidad, la teoría de la pulsión de muerte en Spielrein es una inteligente revisión del funcionamiento de la represión:

13 KERR, John, La historia secreta del psicoanálisis. Jung, Freud y Sabina Spielrein, Crítica. Grijalbo Mondadori, Barcelona, 1995, p. 300. 
la represión del deseo sexual se traduce en la producción de imágenes de muerte y se debe al riesgo del factor destructivo propio de la faceta reproductora de la sexualidad:

'De aquí que el yo siempre respondiera con una actitud de represión ante la activación del deseo sexual, mostrando en la mente imágenes de destrucción y muerte, las cuales representarían las protestas de dicho yo ante la amenaza de su disolución, radicando en ello la última fuente de la represión de los deseos sexuales.' ${ }^{14}$

Así, a diferencia de Freud, en la teoría de Spielrein subyace la idea de que:

'Los conflictos fundamentales que tienen lugar en la mente humana no son el enfrentamiento entre las pulsiones del yo y las pulsiones sexuales, sino, como antes se ha insinuado, entre la vida y la muerte, de modo que la tendencia destructiva humana ha de luchar contra la misma sexualidad: el núcleo de su trabajo es que la destructividad es la última causa de la vida.' ${ }^{15}$

\section{El diálogo de Eros y Thánatos en la obra de Luis Buñuel: sado-masoquismo, fetichismo y destrucción}

La difícil relación de atracción y repulsión, de adecuación y represión, que se produce entre la pulsión de muerte y la pulsión de vida -en otras palabras, entre Thánatos y Eros- encuentra en la figura de Luis Buñuel un caso paradigmático de aplicación. Para estudiarlo habríamos de remitirnos en primer lugar a la teoría freudiana, según la cual la fusión de Eros y Thánatos desemboca en un cúmulo pulsional complejo del que parte una porción energética, proyectada al exterior en forma de violencia dirigida hacia el objeto que ha despertado el deseo libidinal; objeto que, en consecuencia, viene a incomodar la estabilidad del individuo, razón ésta que justifica una respuesta violenta. De acuerdo con Freud, es por este motivo que en la actividad sexual es posible rastrear un componente agresivo, y es por ello que Thánatos también se llama "pulsión de destrucción". Aunque es sobre todo en los casos de actividad sexual anormal o patológica, según Freud, donde esta porción agresiva adquiere personalidad propia en hábitos degenerados que califica de perversiones. Entre ellas, el sado-masoquismo y el fetichismo; manifestaciones que, casualmente, inundan la producción cinematográfica de Luis Buñuel, ferviente admirador, por otro lado, del Marqués de Sade... ${ }^{16}$. En palabras de Freud:

'La tendencia a causar dolor en el objeto sexual o ser maltratado por él es la más frecuente e importante de las perversiones, y sus dos formas, activa y pasiva, han

14 VALLEJO ORELLANA, Reyes y SÁNCHEZ-BARRANCO RUIZ, Antonio, "Sabina Spielrein, la primera mujer que enriqueció la teoría psicoanalítica", en Revista de la Asociación Española de Neuropsiquiatría, vol. XXII, nº. 85, 2003, p. 114.

15 Ibid., p. 113.

16 'Es verdad que en mi cine reflejo con frecuencia a sádicos, masoquistas, etc. Yo no soy así. En realidad, estos tipos me molestan profundamente. Sin embargo, me gusta expresarlos en mis películas porque así es como si me liberase. Sobre todo, me divierto al objetivarlos.' (Luis Buñuel en ALCALÁ, Manuel, Buñuel (cine e ideología), Cuadernos para el diálogo (EDICUSA), Madrid, 1973, p. 126). 
sido denominadas, respectivamente, por Krafft-Ebing sadismo y masoquismo. Otros autores prefieren denominarlo algolagnia, nombre que hace resaltar el placer de causar dolor, la crueldad, mientras que el nombre escogido por Krafft-Ebing acentúa, o pone en primer término, el placer de sufrir toda clase de humillaciones y sometimientos. ${ }^{17}$

Por su parte, Spielrein también supo ver esta cadena relacional, y estableció de forma directa la ligazón entre el componente destructivo presente en la pulsión sexual con el fenómeno sado-masoquista. Es, sin embargo, a Freud a quien debemos atribuir una mayor profundización en la naturaleza del sado-masoquismo. En su opinión, masoquismo y sadismo (que llama perversión de "pares contradictorios") van siempre unidos en la misma persona; lo que ocurre es que una de sus modalidades, es decir, su faceta activa o masculina -sadismo- o bien su faceta pasiva o femenina -masoquismo-, tiene mayor peso que la otra. Séverine, personaje interpretado por Catherine Deneuve en Belle de jour (1967), responde a este esquema dual cuya balanza se deja vencer por el componente masoquista (sadismo dirigido hacia el yo, según lo entiende Freud), tal y como se aprecia en continuas escenas a lo largo de la película:

'En una de ellas se ve avanzar un carruaje por el Bois de Boulogne, a bordo del cual Pierre intenta besar a Séverine. Al ser rechazado por ella, manda parar al cochero y ordena a éste y al palafrenero que aten a su mujer a un árbol y la azoten, recibiendo a continuación permiso para que dispongan de ella como les plazca. Esta escena es interrumpida por una pregunta de Pierre: “En qué piensas?” Y toda la secuencia se convierte en una fantasía diurna de Séverine en su apartamento parisino.' ${ }^{18}$

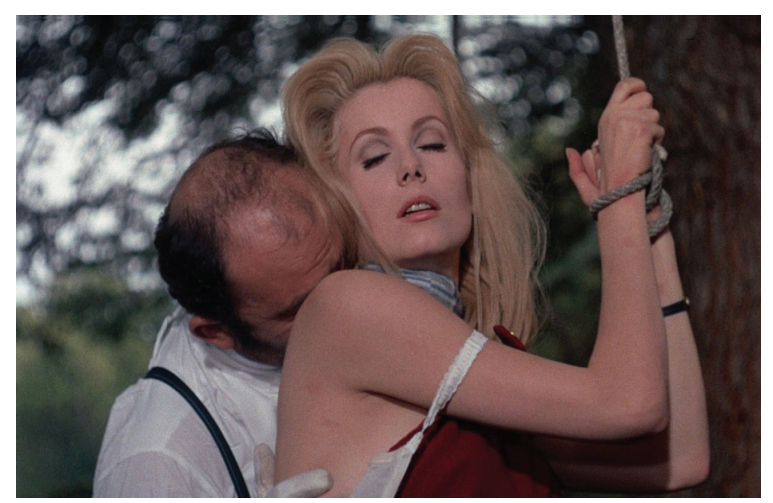

Fig. 1: La fantasía sado-masoquista de Séverine en Belle de jour (1967).

Pero no sólo en escenas de claro contenido sado-masoquista se manifiesta Thánatos; también en otras de sutil violencia psicológica y perversiones destructivas que Buñuel alumbra con frecuencia en sus filmes. Tómese como ejemplo el personaje de Archibaldo de la Cruz en Ensayo de un crimen (1955) y su inclinación "crematoria",

17 FREUD, Sigmund, Tres ensayos sobre teoría sexual, EL PAIS Editorial Biblioteca Nueva, Madrid, 2002, pp. 31-2.

18 SÁNCHEZ VIDAL, Agustín, Luis Buñuel, Signo e Imagen/Cineastas. Cátedra, Madrid, 1991, pp. 255-6. 
que le lleva a quemar en un horno un maniquí de cera que hacía las veces de la mujer que él pretendía. Además, siguiendo a Freud, esta traslación del objeto de deseo y su sustitución por otro en el que se plasman las pulsiones libidinales es un procedimiento que responde al funcionamiento del fetiche, relacionado igualmente con un sentido de la descomposición y fragmentación. Se trata, por tanto, de un objeto o parte del cuerpo que centraliza todo el potencial de la pulsión erótica. Con lo cual, el deseo sexual reprimido por el principio de realidad encontraría vía de escape en la imaginación, y se condensaría en un elemento convertido en "capricho" de su inclinación erótica. En consecuencia, este objeto, o fetiche, será con frecuencia diana de acciones violentas promovidas por la pulsión de Thánatos. Así es como se aprecia en el cine buñueliano incluso en sus inicios, pues es desde Un chien andalou (1929) y su ojo violentamente rasgado al comienzo del filme que podemos hablar de fetichismo destructor en Buñuel. No en vano, ya desde Un chien andalou reconocía Buñuel la carga destructiva de la sexualidad y unía Eros y Thánatos, muerte y excitación sexual, por ejemplo en la secuencia en que el hombre contempla desde la ventana el atropello de la joven andrógina.

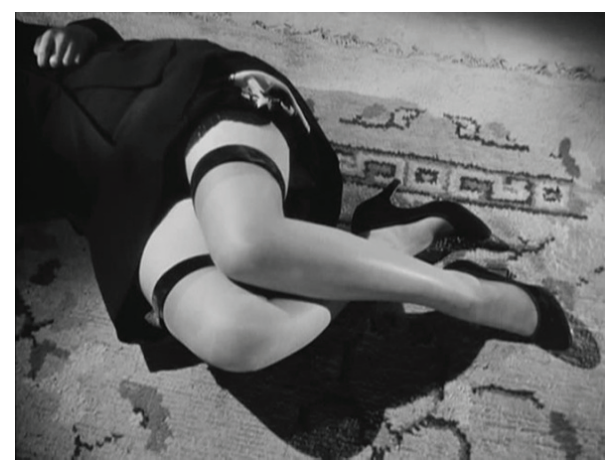

Fig. 2: Muerte y erotismo fetichista unidos en las piernas de la institutriz asesinada; fotograma de Ensayo de un crimen (1955).

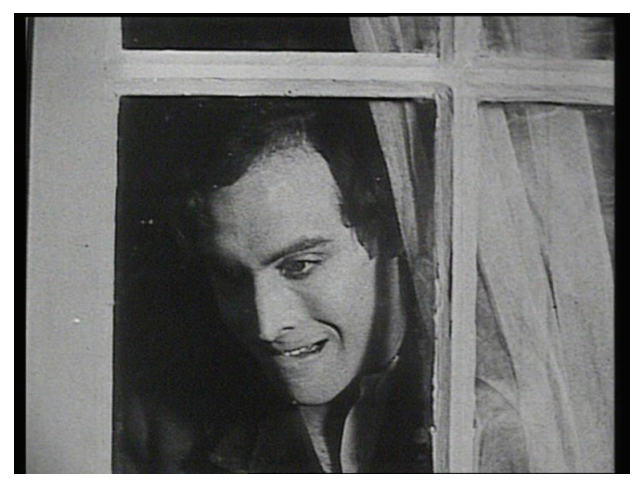

Fig. 3: Un chien andalou (1929): el hombre contempla, deseante, el atropello de la joven andrógina. 
Destrucción y descomposición fetichista de miembros corporales son, pues, rasgos tipificados del cine de Buñuel e inherente característica del modelo de imagen que lo define: la imagen-pulsión, en términos de Gilles Deleuze. Al hablar de la imagenpulsión, Deleuze explica que las pulsiones se apoderan de pedazos del mundo originario, con una inteligencia diabólica, y configura con ellos un mundo derivado, que es un todo desorganizado presidido por la instancia de "pulsión de muerte". Deleuze se refiere a ella como una "violencia muy especial": "La pulsión es un acto que arranca, desgarra, desarticula. ${ }^{19}$ Del entorno real, Buñuel arranca comportamientos de las personas, elementos de las situaciones, y piezas de los objetos, pues 'el objeto de la pulsión es siempre "objeto parcial" o fetiche, trozo de carne, pieza cruda, desecho, braga de mujer, zapato. ${ }^{20}$

Sin embargo, se hace necesario apuntar también que la destrucción de Thánatos en Buñuel no se limita únicamente a la porción desgarrada del fetiche, sino que es una destrucción expansiva que impregna situaciones, personajes, atmósfera y argumento de sus películas. En este sentido, quizá el mejor ejemplo del cúmulo Eros-Thánatos, jalonado por la fuerte impronta de este último componente, en el cine de Buñuel sea la pareja de Alejandro y Catalina en Abismos de pasión (1953), película inspirada en la novela Cumbres borrascosas de Emily Brönte. El salvajismo de la pasión instintiva que se profesan los amantes les hará aproximarse pero también herirse, y sólo podrá culminar en la tragedia de la muerte. Al inicio de la película, un intertítulo advierte al espectador:

"Sus personajes se encuentran a merced de sus propios instintos y pasiones. Son seres únicos para los que no existen las llamadas conveniencias sociales. El amor de Alejandro por Catalina es un sentimiento feroz e inhumano que sólo podrá realizarse con la muerte."

Alejandro y Catalina son individuos poderosamente movidos por las fuerzas de Eros y Thánatos; una agresiva sincronía que estallará en el fatal destino al que se dirigen sin remedio los enamorados. En resumen, lo que plantea Buñuel es casi una revisión de Tristán e Isolda; la historia del amor imposible, sacudida aquí, bajo la cámara del aragonés, por fuertes tensiones pulsionales... No pase desapercibido que la banda sonora de la película está constituida por fragmentos de la ópera Tristán e Isolda de Wagner, compositor que fascinaba a Buñuel desde la adolescencia. Así mismo, una versión de esta ópera wagneriana había sido incluida en La edad de oro (1930), filme que Buñuel reconoce plagado de guiños a Sade, y que relata, en definitiva, la historia de otros "Alejandro y Catalina"; dos enamorados que tratarán por todos los medios de

'reencontrarse venciendo los obstáculos que la sociedad pone de inmediato entre ellos, ya que dos policías se llevan al hombre y unas monjas a la mujer. Sólo la represión del deseo parece asegurar unas bases firmes para la civilización judeocristiana; a

19 DELEUZE, Gilles, La imagen-movimiento. Estudios sobre cine 1, Paidós, Barcelona, 1984, p. 186.

20 Id. 
la inversa, el triunfo del amour fou significaría la vuelta la edad de oro, la de la armonía del hombre con la Naturaleza y los instintos. ${ }^{21}$

Un amor el de La edad de oro que, sin embargo, no está movido por el afán reproductor y perpetuador de la especie, como establecía la teoría de Sabina Spielrein, sino que se queda en la satisfacción del propio deseo individual saciado en el encuentro con el otro. Por lo tanto, de acuerdo con los principios psicoanalíticos, habríamos de puntualizar que Buñuel contempla aquí una pulsión libidinal ajena al poder de Eros y animada por la sombra de Thánatos. Ello se ejemplifica en la voluntad de los amantes de La edad de oro de "matar al hijo", lo que queda recogido en el diálogo que mantienen los protagonistas en la famosa escena del jardín:

- “Qué alegría! ¡Qué alegría haber matado a nuestros hijos!”

- "Mi amor, mi amor, mi amor, mi amor, mi amor".

Junto con esto, apunta Pedro Poyato:

'El tema del filicidio comparece una vez más en el filme, concretamente la escena donde el guardia de la finca la emprende a tiros con su pequeño hijo, a raíz de que éste tire al suelo de un manotazo el cigarrillo que él liaba. Esta es, pues, la doble emergencia del filicidio en el filme: en el diálogo central de la escena de los amantes en el jardín, a través de una palabra directamente implicada en el goce (siniestro) de los padres, y en las imágenes de un padre que, presa de una pulsión incontrolable, remata a su hijo en el suelo, luego de haberle disparado previamente.' ${ }^{22}$

Finalmente, resta decir que hasta en la propia concepción de las imágenes cinematográficas, y ya no sólo desde un punto de vista argumental, la unión indisociable de sexo y muerte condiciona por sí misma la estética buñueliana. Para el cineasta no era posible comprender la sexualidad desgajada de un angustioso sentido de la muerte, de la destrucción, de lo agresivo, e incluso de lo funerario; obsesión que le persigue desde su infancia y temprana juventud en tierras aragonesas. De ahí que la "iconografía" cinematográfica de Buñuel esté poblada hasta el extremo de secuencias que unen ambos extremos pulsionales, y que adquieren por sí mismas una entidad autónoma, justificada en virtud de la fuerza de su propio diálogo interno entre Eros y Thánatos. Un claro ejemplo aparece en Tristana (1970), relacionando el elemento fálico del campanario con la decapitación del padre-amante, en la onírica y turbadora imagen de la cabeza seccionada de don Lope, que hace las veces de badajo de la campana. ${ }^{23}$ Como indica Poyato, 'sexo y muerte terminan así aunados, anudados en torno a esa

21 SÁNCHEZ VIDAL, Agustín, op. cit., p. 136.

22 POYATO SÁNCHEZ, Pedro, El sistema estético de Luis Buñuel, Comunicación. Universidad del País Vasco, Bilbao, p. 50.

23 No se obvie el rol del campanario en el universo sexual de Salvador Dalí, que visualizaba estas construcciones en sus orgasmos, según relata en múltiples testimonios autobiográficos: 'Gala es la única mujer en la que me vacío, con un orgasmo rápido y perfecto, poblado de imágenes arquitectónicas de sublime belleza: principalmente campanarios...' (Salvador Dalí en SÁNCHEZ VIDAL, Agustín, Buñuel, Lorca, Dalí: El enigma sin fin, Planeta, Barcelona, 2009, p. 99). 
imagen-pulsión de la figura paterna descabezada. ${ }^{24}$ Parece que el propio cineasta quisiera respaldar esta interpretación cuando le cuenta a Max Aub:

'Las campanas de Calanda. Que tocan todo el día, ¿quién muere? Campanas, campanas a misa, al rosario, al toque de la agonía. [...]. Una visión de muerte continua y el sentido del pecado. ¡Figúrate, a mí! Pero no lo puedo impedir, no lo puedo separar. Para mí -instintivamente- el coito es algo infernal. ${ }^{25}$

\section{Dalí: de la mantis religiosa a la metamorfosis de Narciso}

En el análisis dedicado a Luis Buñuel veíamos que el objeto de su deseo era eminentemente externo y que, precisamente por eso, al experimentar la incomodidad de tener que saciar un displacer motivado por tal objeto, ejercía sobre él acciones destructivas, siendo el resultado de ello síntomas sado-masoquistas y fetichistas. A diferencia de Buñuel, su amigo y compañero en la Residencia de Estudiantes, Salvador Dalí, con quien realizaría la mítica película Un chien andalou, desarrolla una dinámica de autoconservación de diferente índole, casi contrapuesta, ya que durante su adolescencia y juventud Dalí responde a un perfil de incuestionable carácter narcisista. En palabras de Freud, este concepto, "narcisista", designa el hecho de que un individuo "conserve su libido en el yo y no destine ninguna parte de ella al revestimiento de objetos. ${ }^{26}$ Dicho de otro modo, el narcisista es aquel cuya libido no se proyecta en objetos de deseo externos, sino que se contiene y limita en el propio yo, cayendo, por tanto, en el autoerotismo; una de las desviaciones respecto al fin sexual normal, que según Freud, define a los pervertidos, al igual que a los desviados (fetichistas) e invertidos (homosexuales). Se trata, pues, de un amor hacia sí mismo y no un amor de objeto; es decir, no un amor dirigido a otra persona, sino un amor cuya energía se aplica el propio individuo. Es por eso que se llama "libido del yo" o "libido narcisista", de naturaleza no procreadora, y que, según Freud, aparece en la primera infancia:

'A este estado lo denominamos narcicismo absoluto primario; subsiste hasta que el yo comienza a cargar las representaciones objetales con libido, es decir, a convertir la libido narcisística en libido objetal. ${ }^{27}$

Un incuestionable narcisismo y acusado autoerotismo, que quedaría personalizado en el conocido lienzo El gran masturbador (1929), lleva a Dalí a desarrollar una fuerte tendencia onanista y manía masturbatoria, que le hace saciar sus impulsos al margen del contacto físico con el sujeto de deseo ajeno a él. Como Narciso, Dalí se contenta consigo mismo, "enamorado de su propia imagen". Relataba el propio Dalí que a su llegada a París recorrió los mejores burdeles, pero sólo para verificar que encontraba satisfacción en la masturbación acompañada de la visualización del

24 POYATO SÁNCHEZ, Pedro, op. cit., p. 176.

25 AUB, Max, Conversaciones con Buñuel. Seguidas de 45 entrevistas con familiares, amigos y colaboradores del cineasta aragonés, Aguilar, Madrid, 1985, p. 41.

26 FREUD, Sigmund, Psicología de las masas (...), (2003), op.cit., pp. 130-1.

27 FREUD, Sigmund, Esquema del psicoanálisis, Paidós, Buenos Aires, 1966, p. 19. 
cuerpo desnudo de la prostituta, eso sí, alejada de él en la esquina opuesta de la habitación. Así, según comenta Antonio Lara, la imagen que para Dalí simbolizaba el amor perfecto

'consistía en dos enamorados, separados por unos cuantos metros, totalmente vestidos, que se contemplaban intensamente, sin tocarse, hasta llegar a un violento orgasmo.' 28

De hecho, el placer daliniano tiene mucho de voyeurismo, de disfrute erótico de las imágenes, y está muy relacionado con los orgasmos "visuales", según testimonio del artista. No extraña entonces que, pasados los años, desarrollara la afición de inventar juegos eróticos "no consumados" en los que intervenían varias personas:

'Imagino los refinamientos eróticos más complicados, las combinaciones más hábiles, las situaciones más deliciosamente imposibles [...]. Pero mi deseo más ardiente es que no suceda nada. ¡Nada! Ni siquiera un contacto entre todos esos seres [...]. ¡ $\mathrm{Ni}$ siquiera un roce! ${ }^{29}$

Todo esto no puede entenderse al margen del "cledalismo", terminología de invención daliniana para referirse a este peculiar modo de inclinación erótica -unión visual con el objeto en la sublime desunión con el mismo-, que Dalí ejemplifica en la novela de recargada prosa Rostros ocultos. En sus palabras: 'El cledalismo es el placer y el dolor sublimados por una absoluta identificación trascedente con el objeto. ${ }^{30}$

Ahora bien, llegados a este punto cabe preguntarse a qué se debe el hiperbólico narcisismo del joven Dalí. La respuesta se halla, una vez más, en la difícil convivencia de Eros y Thánatos, sobre todo a causa de los ingredientes de violencia que contiene dicho binomio pulsional. Y es que Dalí sentía horror a las demandas contundentes del acto sexual y sus implicaciones agresivas, viéndose a sí mismo incapaz de llevarlo a cabo (miedo a la impotencia y desconfianza en el propio vigor físico) y considerándose, además, como la víctima de las pulsiones asesinas e incontrolables de la otra persona. 'No me hagas daño. Prométemelo. Nunca nos haremos daño' ${ }^{31}$, le suplicaría Dalí a Gala en la etapa primera de su relación. Dalí, ferviente freudiano, quedaría sin duda profundamente impresionado ante determinadas afirmaciones del padre del psicoanálisis formuladas en esta línea:

'Las modificaciones de la proporción en que se mezclan los instintos tienen decisivas consecuencias. Una mayor dosis de agresión sexual convierte al amante en asesino perverso; una gran atenuación del factor agresivo le torna tímido e impotente. ${ }^{32}$

28 LARA, Antonio, "El amor y el cine", en Revista de Occidente, n ${ }^{\text {os }}$ 15-16 (Extraordinario III: sobre el amor), 1982, p. 182.

29 DALÎ, Salvador, Textos autobiográficos (las pasiones según Dalí; Confesiones inconfesables), 2, Fundació Gala-Salvador Dalí, Barcelona, 2003, p. 130.

30 DALÍ, Salvador, Rostros ocultos, Plaza \& Janés, Barcelona, 1983, p. 9.

31 DALÍ, Salvador (2003), op.cit., p. 407.

32 FREUD, Sigmund (1966), op.cit., p. 17. 
Esta fobia de Dalí a ser agredido y destruido en la unión sexual adquiere valores, por así decirlo, "comestibles", pues se trata, en resumidas cuentas, del miedo a ser "engullido" o "asumido" por el otro de cara a su propia nutrición en la violencia libidinal desatada por la tensión Eros-Thánatos. De hecho, el propio Freud ya entablaba conexiones entre estos dos tipos de acciones:

'El acto de comer representa una destrucción del objeto con la finalidad de la incorporación; el acto sexual, una agresión con el propósito de la más íntima unión. ${ }^{33}$

Si además se tiene en cuenta, como le ocurría a Dalí, que en lo relativo a la unión sexual el hombre puede padecer el terror de ser utilizado por la mujer como medio para la obtención de un fin deseado -el hijo-, el hecho de "ser devorado" adquiere entonces un añadido sustancial, que se proyecta en un especial miedo a lo sexualcanibalístico; dicho de otra manera, al canibalismo como acto de amor. Recordemos, tal y como señalaba Spielrein, esa voluntad reproductora y de conservación de la especie inherente a la pulsión sexual, para cuyos objetivos era necesaria la violencia destructora ejercida sobre el otro. Se trata, en realidad, de un procedimiento presente en la naturaleza, y especialmente común en muchos insectos, siendo la hembra la que devora a su compañero una vez consumado el coito. Entre ellos, y junto a la imponente viuda negra, ostenta significativa importancia la mantis religiosa, que se vuelve muy agresiva durante el apareamiento, llegando incluso a devorar al macho. Todo esto no era desconocido para Dalí, lector de las obras de entomología de J. H. Fabre, a las que le aficionó precisamente Buñuel, muy influenciado por el mundo de los insectos. En concreto, Dalí se verá hondamente turbado por el comportamiento de la mantis religiosa, para él asociable al riesgo que entrañaban las mujeres y el acto sexual. En pocas palabras, Dalí se identificaba con el macho de la mantis religiosa, indefenso ante la hembra y víctima mortal de su ansia asimiladora y destructiva, encaminada a la reproducción. ${ }^{34}$

Para Dalí, esta convicción queda vinculada, de forma icónica, al cuadro de $E l$ Ángelus de Millet; obra que afectó al pintor ya desde la infancia, y que le perseguirá cual delirante obsesión a lo largo de su vida. La razón de ello reside en que, en opinión de Dalí, la imagen pintada por Millet resume el instante pre-sexual en la mantis religiosa, de manera que hombre y mujer reproducen en el lienzo las actitudes que estos insectos adoptan en el momento previo al apareamiento. Es por eso que, en opinión de Dalí, el cuadro alberga un amedrentador contenido erótico que anuncia la

33 Id.

34 'Según este autor [Fabre], cuando maduran los ovarios de las hembras de mantis religiosa, se apodera de ellas un tremendo frenesí agresivo, no justificado por el hambre ni por los celos, que las conduce a entablar tremendas batallas con los miembros de su misma especie [...] Pero hay más: si se aísla a estos animales por parejas de distinto sexo, se observa que, tras un acoplamiento pacífico de unas cinco horas, el macho es agarrado por su compañera "que le roe primero la nuca, siguiendo los usos y costumbres, y después, metódicamente, a pequeños bocados, le consume, no dejando más que las alas. No se trata de celos de harén entre miembros del mismo sexo sino de ansia depravada". [...] Los surrealistas encontraron seductora esta materialización en la naturaleza de la aspiración oculta y fantaseada que ellos percibían en el amor fou.' (RAMÍREZ, Juan Antonio: Dalí: lo crudo y lo podrido. La Balsa de Medusa, 124. Antonio Machado Libros, Madrid, 2002, pp. 52-3). 
destrucción del hombre, devorado por la mujer. Así, acerca de la posición de la mujer en el cuadro de Millet, comenta Dalí:

'Comporta a mi modo de ver un factor exhibicionista, un factor expectante y un factor de agresión clarísimos. Está claro que se trata de la típica postura de espera. Es la inmovilidad que preludia las violencias inminentes. Es también la clásica actitud de los saltos de animales, es la común al canguro y al boxeador; y, sobre todo, la que ilustra con resplandor la mantis religiosa (actitud espectral). ${ }^{35}$

En consecuencia, es lógico concluir, como hace también Dalí, que el miedo que siente hacia el acto sexual -representado en la mantis religiosa/Ángelus de Millet- es equiparable al miedo a la muerte, es decir, al miedo a la propia destrucción. El pintor resume en las siguientes palabras la particular vinculación que, desde este punto de vista, mantiene con el cuadro de Millet:

'El terror que nos causa su aparición en el marco del museo corresponde, como ya se ha señalado, al terror de la muerte, de la muerte que, supongo, no puede ser otra cosa que la consecuencia de ese acto feroz, eminentemente trágico y desproporcionado para mis capacidades fisiológicas y vitales. Siempre había pensado que el destino del macho de la mantis ilustraba mi propio caso frente al amor.' ${ }^{36}$

A pesar de todo, en determinada etapa de su producción pictórica, Dalí recurriría con frecuencia a la composición de Millet para reinterpretarla en sus obras, quién sabe si como tratamiento catártico de los propios miedos. Por ejemplo, se detecta su influencia en El "Ángelus" arquitectónico de Millet (1933), Atavismos del crepúsculo (obsesiones) (1933-4), y Reminiscencia arqueológica del “Ángelus” de Millet (1935).

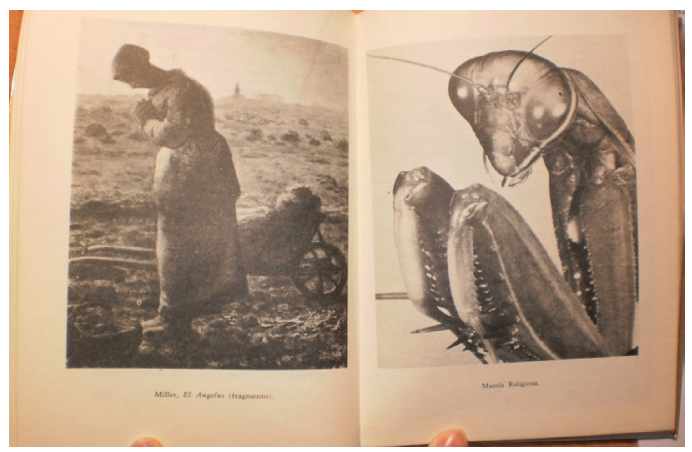

Fig. 4. Dalí compara estas dos fotografías para ilustrar las concomitancias entre el amenazante acecho de la mantis religiosa y la actitud orante de la mujer en El Ángelus de Millet. Dicho paralelismo no resulta del todo extraño si se tiene además en cuenta que este tipo de insecto, entre cuyas variantes se encuentra la mantis religiosa -conocida en España como "santa teresita"-, recibe precisamente el nombre de "mantis" por la posición de sus patas delanteras, que recuerda la postura flexionada de los brazos durante el rezo (el término griego mantis significa "profeta").

35 DALÍ, Salvador, El mito trágico del "Ángelus" de Millet, Tusquets, Barcelona, 1978, p. 69.

36 Ibid., p. 84. 


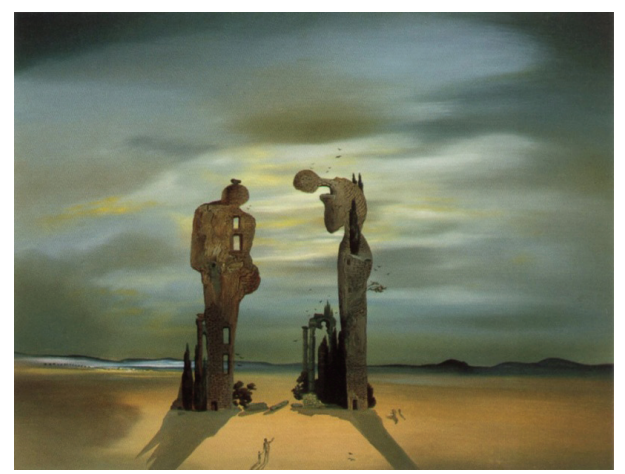

Fig. 5. Dalí: Reminiscencia arqueológica del “Ángelus” de Millet (1935).

De este modo, nos encontramos con que, básicamente, el miedo de Dalí a la "mantis religiosa", es decir, a ser destruido por la mujer en el acto sexual, no es más que miedo a la muerte, al sufrimiento y a la desaparición del propio yo, diluido además para gestar otra vida. Por tanto, podríamos afirmar que es el miedo que se deduce de la confrontación Eros-Thánatos según el análisis que desarrollaba Sabina Spielrein en su teoría sobre la pulsión de muerte. En este sentido, el hijo supone un elemento que incrementa la amenaza contra la integridad del yo, puesto que favorece las energías agresivas del instinto sexual de acuerdo a ese subconsciente colectivo que señalara Spielrein. Si, como vimos, Buñuel mataba a sus "hijos" -en el mundo de la ficción cinematográfica-, Dalí se opone a engendrarlos biológicamente y biográficamente; el genio de Dalí no será heredado, no habrá personalidad transmitida, "reproducida"... Y es que el miedo narcisista a la destrucción del yo también adopta esta faceta: evitar el hijo, que resulta un atentado a la constitución del yo, a la autoconservación. No en vano, como dice Spielrein, 'el miedo al amor es el miedo a la muerte de la propia personalidad.' ${ }^{37}$ Según explica Dalí:

'No tenemos hijos. Y no lo lamento. [...] en el fondo, no deseo que haya seres que lleven mi nombre. No deseo transmitir a Dalí. Quiero que todo termine conmigo. [...]. Además, mi amor por Gala es mundo cerrado, pues mi mujer es el punto indispensable que cierra mi propia estructura.' ${ }^{38}$

Gala, dice Dalí, 'es el único ser con el que deseo fundirme. ${ }^{39}$ Fundirse, que no procrear (recordemos que la libido narcisista no es una libido reproductora). Pero obsérvese que ya habla de su amor por Gala y del deseo de fundirse con ella; revelador avance para un sujeto narcisista como es Dalí. Por tanto, Dalí está experimentando un cambio: con la aparición de Gala, está logrando superar la visión de la mujer como mantis religiosa, como femme fatale devoradora y reproductora (visión que, por otro lado, es común a otros artistas, también temerosos del sexo y la muerte, como Edvard

37 KERR, John, op. cit., p. 345.

38 DALÍ, Salvador (2003), op.cit., pp. 66-7.

39 Ibid., p. 61. 
Munch). En pocas palabras, Dalí está mutando la libido del yo, la libido narcisista, por la libido objetal. Así pues, podemos decir que Dalí no modifica su infantilismo libidinal hasta que conoce a Gala, que se convierte en la receptora de su libido. De hecho, según el pintor, fue Gala quien le curó de su enfermizo narcisismo. ${ }^{40}$

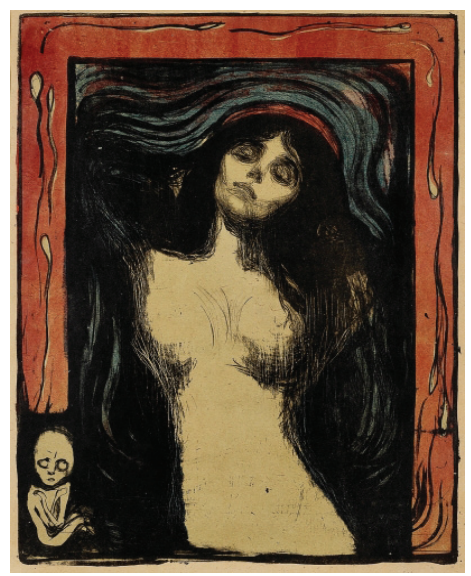

Fig. 6: Munch: Loving woman - Madonna (1895-1902). La mujer es un cebo fatal para el hombre, utilizado para el fin reproductivo, como evidencia el feto que aparece en la esquina de la composición, resultado de los espermatozoides que pululan por el marco fingido.

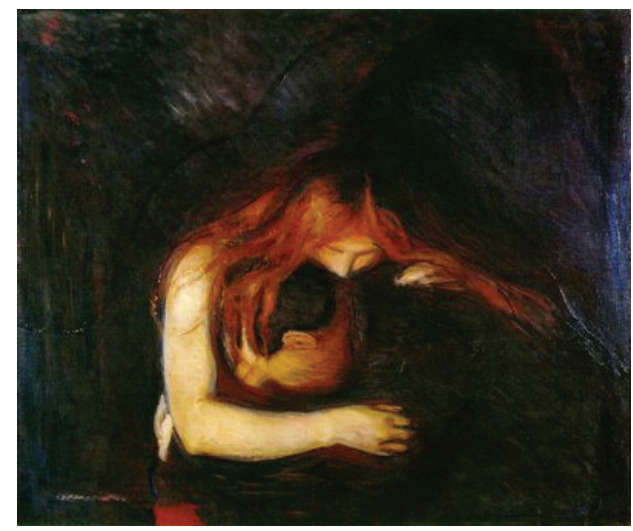

Fig. 7: Munch: Vampiresa (1894). La visión de Munch de la mujer, de pelirroja melena, como devoradora del hombre. Casi una mantis religiosa.

40 'Es una época [los años de juventud en Madrid] en que viví bajo el terror del acto del amor, al que confería caracteres de animalidad, de violencia y ferocidad extremas, hasta el punto de sentirme completamente incapaz de realizarlo, no sólo a causa de mi supuesta insuficiencia fisiológica, sino también por miedo a su fuerza aniquiladora, que me hacía creer en consecuencias casi mortales. Este terror se había apoderado de mí con violencia durante el principio de mis relaciones con Gala, principio que marcaba una crisis decisiva en mi vida erótica ya que el amor de Gala debía operar una verdadera cura psíquica [...].' (Ibid., pp. 81-2). 
En resumen, Dalí-Narciso ha sustituido su propia imagen por un objeto de deseo externo: el espejo de Narciso ya no es la superficie cristalina del agua que le ofrece su reflejo; ahora su espejo es Gala, en ella se plasma a sí mismo y de ella recibe su reflejo, como los niños pequeños lo reciben de su madre en la lacaniana fase del espejo. Así pues, Narciso se ha metamorfoseado. Esta evolución erótico-pulsional que experimenta Dalí marcará un antes y un después en su producción pictórica, la cual, habiendo conocido con anterioridad las obsesivas imágenes de El Angelus de Millet, variará radicalmente tanto en temática como en "espíritu" bajo la influencia indeleble de Gala. El cuadro que marca este hito no podía ser otro que La metamorfosis de Narciso (1937), cuadro que Dalí mostró a Freud cuando se conocieron en Londres en 1938 por mediación de Stefan Zweig, y que además, lleva aparejado un poema de idéntico título en el que el artista explica el contenido conceptual del lienzo:

\author{
Mas tú, Narciso, \\ formado por tímidas eclosiones perfumadas \\ de adolescencia transparente, \\ duermes como una flor de agua. \\ Ahora se aproxima el gran misterio, \\ ahora tendrá lugar la gran metamorfosis. \\ [...] \\ Cuando esa cabeza se raje, \\ cuando esa cabeza estalle, \\ será la flor, \\ el nuevo Narciso, \\ Gala, mi narciso.
}

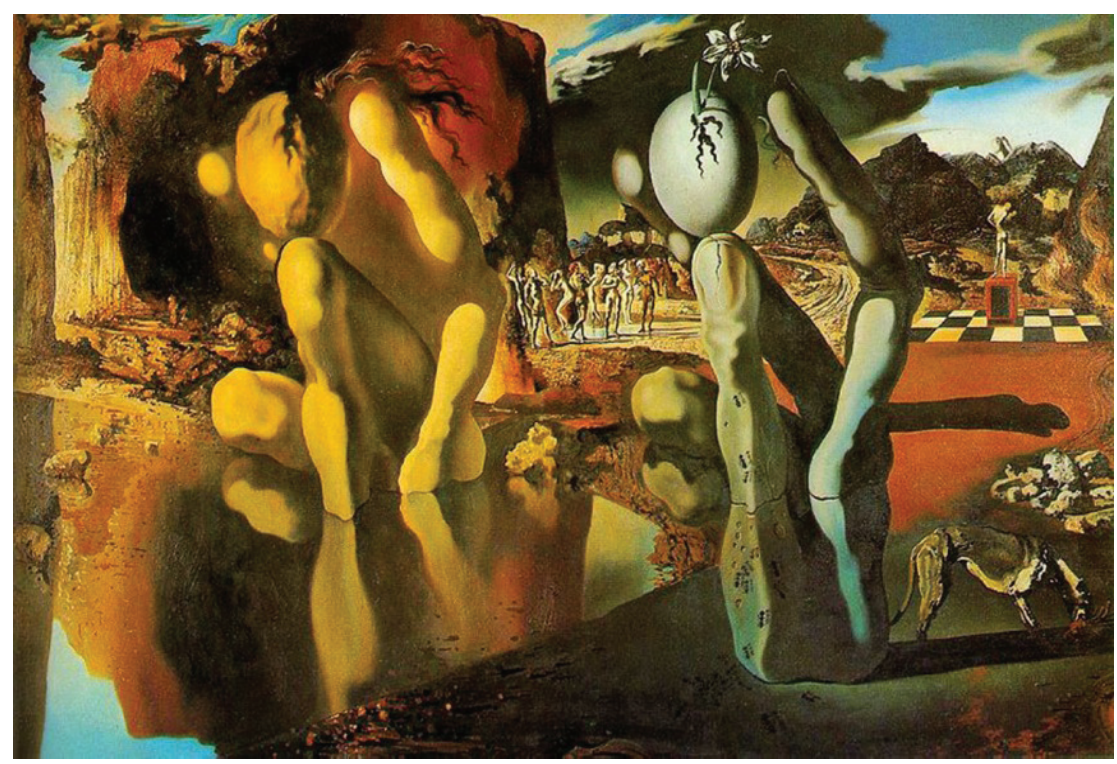

Fig. 8: Dalí: La metamorfosis de Narciso (1937). 


\section{Federico García Lorca o el miedo (amor) a la muerte}

El miedo a la muerte (a la destrucción del yo) relacionado con lo sexual se manifiesta de distinta manera en Buñuel y Dalí. Por lo que afecta al primero, hemos visto que este miedo se traduce en una dinámica de agresión sado-masoquista y fetichista, mientras que en el segundo adopta una mecánica defensiva de corte narcisista. Estas son, por tanto, las modalidades según las cuales la pulsión de autoconservación, Thánatos, opera en cineasta y pintor para reprimir la pulsión de Eros. Corresponde a continuación estudiar las herramientas que, encaminadas a dicho fin, aplicará el tercer integrante de este grupo de amigos de la Residencia de Estudiantes, el poeta, músico, dramaturgo, y artista integral, Federico García Lorca.

A este respecto es bien conocido el profundo miedo que sentía el granadino por la muerte, tema que sin embargo protagoniza buena parte de su repertorio poético. De hecho, la Muerte es para Lorca su principal amiga inspiradora, a la par perenne y telúrica amenaza que brota en diferentes excusas temáticas, ya sea la luna, la navaja, o la niña ahogada en el pozo. Pero lo más interesante es sin duda el motivo de la propia muerte, que se hace dramáticamente reiterativo en Lorca. Se trata de una obsesión que le acompañará siempre, no sólo en su obra, sino también en su vida cotidiana. De hecho, cuenta la anécdota que no había día en que Lorca no hablara en varias ocasiones de su muerte. Da la impresión de alguien que pretendiese ahuyentar un miedo hablando constantemente de él; y no sólo hablando, pues Lorca llega a asumir su miedo de una forma tan íntima en su propia persona que acaba por representarlo en una especie de lúgubre escenificación. Según Dalí, era ésta una práctica habitual de Lorca durante sus años en la Residencia de Estudiantes:

'García Lorca, mi mejor amigo de la juventud, tal vez nos desvelaba algún secreto aprendizaje gitano cuando nos escenificaba su propia muerte. Se tumbaba en la cama, cerraba los ojos, se ponía rígido y contaba los días. Su rostro se iba tornando cada vez más terrible a medida que sus muecas imitaban su descomposición progresiva. Al quinto día -jahora llega el primer día!, decía él-, le enterraban. Nos describía el momento en que cerraban el ataúd, y luego el coche fúnebre, que le llevaba traqueteando por las calles mal adoquinadas de Granada. Y al final se producía una especie de apoteosis. Sus rasgos se relajaban, sus labios sonreían. Entonces, se incorporaba y nos sacudía la desazón prorrumpiendo en una risa brutal, mostrándonos todos sus dientes blanquísimos. Luego nos marchábamos. Nos contemplaba mientras nos íbamos, triunfante, pues había transferido su angustia a nuestro grupo, ahora ya podía meterse en la cama y dormirse tranquilamente. ${ }^{41}$

Parece ser que Lorca no se dormía hasta que sus compañeros "iban a acostarle" y asistían a su acostumbrado número funerario. Desde un punto de vista psicoanalítico, semejante fenómeno tiene mucho que ver con la explicación que da Freud a la compulsión de repetición en Más allá del principio del placer. En este texto Freud analiza el hábito de un niño pequeño (en realidad, su propio nieto) de repetir el gesto de arrojar-recuperar un juguete; objeto que reaparecía, para alegría del niño, después

41 Ibid., p. 83 
del sufrimiento de haberlo visto desaparecer. Esta acción es extrapolable a muchos otros casos de la vida infantil más complejos, pero que funcionan de idéntica forma. Una de las conclusiones a las que llega Freud es que los niños convierten en juego aquellos sucesos que les resultan desagradables, tornándolos en algo divertido y condensándolos en situaciones que ellos pueden controlar y manipular; como indudablemente hacía también Lorca en esa especie de juego en el que repetía su muerte para volver después a la vida, estallando en risotadas de niño grande, amo y libertador de sus miedos:

'Se ve que los niños repiten en sus juegos todo aquello que en la vida les ha causado una intensa impresión y que de este modo procuran un exutorio a la energía de la misma, haciéndose, por decirlo así, dueños de la situación. ${ }^{42}$

Por tanto, por medio del juego repetitivo se logra un dominio de la situación a la que se teme; repetición que, en consecuencia, se convierte en el modo de mantener la estabilidad de un yo que se sabe amenazado. Así pues, la compulsión de repetición se erige en una manifestación más de Thánatos. En otras palabras, el instinto de autoconservación es el que incita a la repetición de acciones de displacer, porque encuentra en ello una vía para saciar la energía pulsional reprimida, de forma que el acto repetitivo se convierte en un recurso básico para satisfacer el displacer y ayudar al retorno a un estado de equilibrio. No en vano, Freud entendía la compulsión de repetición como un claro síntoma de la pulsión de muerte. De esta forma, al imponerse como vivencia el proceso de su propia muerte y descomposición, Lorca está intentando calmar la actividad de Eros, que vive camuflada en ese mítico miedo a la muerte que caracterizaría siempre al poeta. Y es que la repetitiva proyección de semejante escena de destrucción es, en realidad, como exponía Spielrein, un medio de represión de la pulsión de Eros, auxiliado por la creación de imágenes de muerte. Como puede apreciarse, Lorca emplea un recurso distinto a los reseñados en Buñuel y Dalí; él se vale de la producción de otro tipo de imágenes de muerte y destrucción, en concreto, las de su propia muerte y destrucción, para reprimir así la pulsión de vida y retornar a un estado de estabilidad.

Por otro lado, cabría suponer que el componente reproductivo de Eros, que también señaló Spielrein, no debiera ser, en teoría, un acicate agresivo en el caso de un amor homosexual, como es el de Lorca. Sin embargo, este aspecto resiste y permanece como una rémora de "agua que no corre", en términos lorquianos, obstruyendo el fluido pulsional y contribuyendo a una mayor represión erótica. "Mis hijos que no han nacido / me persiguen" dirá Lorca en el poemilla "Arco de lunas". Le persiguen, aunque él los busca (en el poema "Iglesia abandonada (Balada de la Gran Guerra)" de Poeta en Nueva York), y le torturan internamente (quizá por eso Lorca se refería a la masturbación como "el sacrificio del semen"...). Todo esto no es extraño en opinión de Gibson:

'El joven Lorca había tratado ya el tema del instinto maternal frustrado en "Elegía" (1918), de Libro de poemas, y tarde o temprano tenía que aflorar en el teatro, donde

42 FREUD, Sigmund, Psicología de las masas (...), (2003), op.cit., p. 95. 
Yerma sería su máxima expresión. Lorca, siendo quien era, no podía por menos de especular sobre la que ha llamado José Ángel Valente "naturaleza no germinativa de la relación homosexual", y relacionarla con la tristeza de las mujeres que, deseando tener un crío, no pueden. ${ }^{43}$

Yerma es la materialización del trauma de la mujer no reproductora con la que Lorca se identifica hasta cierto punto, pues Lorca es yermo también. Lorca busca al hijo y lo rastrea a lo largo de toda su obra, y así se evidencia incluso en piezas de su "teatro imposible", caso del diálogo del Maniquí y el Joven en El público:

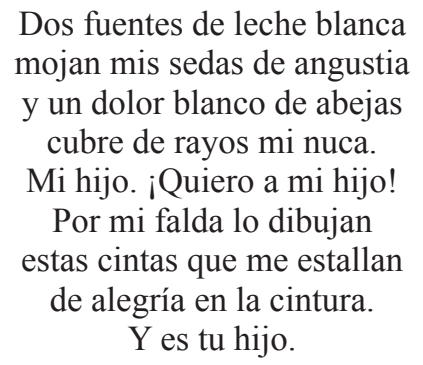

La esterilidad de Yerma se ve además acusada por el hecho de que ella, realmente, no está enamorada de su marido. Ella ama a otro, al joven pastor Víctor, y en el esposo sólo busca al hijo..., que no llega:

"Mi marido es otra cosa. Me lo dio mi padre y yo lo acepté. Con alegría. Ésa es la pura verdad. Pues el primer día que me puse de novia con él ya pensé... en los hijos... Y me miraba en sus ojos. [...]. Yo me entregué a mi marido por él, y me sigo entregando para ver si llega, pero nunca por divertirme."

Es, pues, realmente significativa la frustración de las mujeres lorquianas en busca del amor inalcanzable, desde Soledad Montoya a Doña Rosita la soltera. Como excepción, y tras superar abismales impedimentos, Adela, en La casa de Bernarda Alba (subtitulado "drama de la sexualidad andaluza"), logra el amor ansiado de Pepe el Romano, pero este amor consumado termina seguidamente con una muerte drástica. En Lorca, sexo y muerte quedan, también, íntimamente unidos; como de igual modo ocurre en la escena final de Yerma, en la que el acto sexual, umbral de vida, aúna por medio del gesto asesino de la protagonista la destrucción del marido con la del hijo, terminando con la terrible exclamación de Yerma: "¡Yo misma he matado a mi hijo!". Y también como Yerma, Lorca termina "matando a sus hijos" a través de la afeminada personificación del cómico americano Buster Keaton, según lo perfila el poeta en su Paseo de Buster Keaton, texto en el que los cuatro supuestos hijos de Buster perecen a manos de su padre, que los mata con un puñal de madera. Los hijos son, de nuevo, una amenaza contra el yo y el amor que le abrasa, ya que como dice Spielrein:

43 GIBSON, Ian, Lorca y el mundo gay. Caballo azul de mi locura, Planeta, Barcelona, 2010, p. 333. 


\begin{abstract}
'Ser fértil significa, en verdad, destruirse a sí misma, porque con el nacimiento de la generación sucesora, la anterior ha superado su punto álgido: así, nuestros descendientes son nuestros enemigos más peligrosos, a quienes no podemos vencer, porque nos sobrevivirán y por lo tanto nos arrebatarán, sin remisión, el poder de nuestras manos debilitadas. [...]. Ello aclara las fantasías de muerte que de inmediato acompañan a toda renuncia al deseo erótico.' ${ }^{44}$
\end{abstract}

Se hace evidente, entonces, que la ambivalencia de Eros y Thánatos, matrimonio siempre en discordia, halla claro reflejo en Lorca, quien se dirige a él llamándolo por su nombre en la instintiva percepción de su difícil dualidad ("Amor de mis entrañas, viva muerte" 45 ), ante cuyos riesgos, sin embargo, el poeta no claudica: " $i$ Amor! Enemigo mío, / ¡muerde tu raíz amarga!". ${ }^{46}$ Porque Lorca no descansa en la obsesiva búsqueda del amor que le rehúye, y así lo declara en el "Poema doble del lago Eden", quizá uno de los más significativos de Poeta en Nueva York:

Pero no quiero mundo ni sueño, voz divina, quiero mi libertad, mi amor humano

en el rincón más oscuro de la brisa que nadie quiera.

¡Mi amor humano!

\title{
6. Ideas conclusivas
}

Los análisis efectuados en estas páginas en torno al fenómeno de la sexualidad y la muerte - como producto de la rivalidad de Eros y Thánatos- en Buñuel, Dalí y García Lorca permiten una aproximación a la comprensión de esa constante presencia y profunda huella que el dramático binomio imprime en la vida y obra de estos tres creadores, partícipes insoslayables del ambiente surrealista en España. El objetivo de estas incursiones interpretativas llevadas a cabo en el presente artículo se extiende, por tanto, más allá de una simple enumeración de elementos que respalden la participación de esta destructiva realidad en el universo de Buñuel, Dalí y Lorca. La finalidad de este estudio consiste, más bien, en observar el referido fenómeno pulsional bajo una nueva luz (hasta ahora ampliamente ignorada): la luz que arrojan las teorías psicoanalíticas de la pulsión de muerte, para a partir de las mismas alcanzar el ulterior propósito de entender la dinámica y razones funcionales que lo sostienen. Dicho brevemente, el objetivo principal no ha sido otro que desmenuzar, con espíritu analítico, los mecanismos internos en virtud de los cuales operan Eros y Thánatos en el caso de estos artistas; ampliando, además, las perspectivas teóricas: no limitando solamente el horizonte referencial a las fuentes freudianas, sino considerando también los ecos argumentales que de la propuesta de Spielrein pudieran hallarse en este panorama de variadas influencias.

44 KERR, John, op. cit., pp. 306-7.

45 En el poema "El poeta pide a su amor que le escriba", de El Diván del Tamarit.

46 En el poema "Gacela de la raíz amarga", de El Diván del Tamarit. 
Llegados a este punto resulta viable concluir la existencia de una perenne problemática experiencial de idéntica naturaleza, común a los tres amigos de la Residencia de Estudiantes, si bien en cada uno de ellos se materializará a través de diferentes cauces y acciones concretas. Así, se hace evidente que, por medio de sus respectivos mecanismos expresivos, Buñuel, Dalí y Lorca estarán siempre inevitablemente domeñados por la sombra de la putrefacción, el miedo a la muerte y una misteriosa noción trágica de lo sexual. Lo indiscutible de esta realidad no facilita, sin embargo, establecer un diagnóstico uniforme que explique este obsesivo imperio de la sexualidad angustiada, hermanada con la muerte. Resulta, en verdad, complejo aventurar una conclusión contundente e inapelable al respecto de las razones que derivan en este perfil psicológico, pero sin duda, buena parte de ellas se localiza en el contexto que esbozábamos en el apartado introductorio, entre cuyos parámetros encajábamos el discurrir existencial de los tres autores objeto de estudio.

Nos referimos a un escenario histórico-social concreto, a nivel europeo, y particularmente nacional, mecido por el estallido del movimiento surrealista en Francia y por el significativo auge del psicoanálisis; corrientes que, marcadas también por esa antinomia de Eros y Thánatos, comienzan a ser asumidas por estos artistas durante los años de su etapa "residencial" - sobre todo Buñuel y Dalí, apasionados lectores de Freud. Todo esto quedaría incompleto si no se tuvieran así mismo en cuenta otros factores de carácter biográfico, personal y actitudinal que definen y articulan los sujetos creativos que fueron Buñuel, Dalí y Lorca. De ahí también el por qué de la importancia de incluir determinadas experiencias vitales de dichos artistas y la evolución que en muchos casos las jalonan; experiencias que están, además, condicionadas en un importante porcentaje por el poso de una tradición social y educativa de corte burgués, religioso-católica, y sexualmente represiva, contra la que reacciona este trío de amigos, pero en la que irremediablemente hunden sus raíces tanto en su formación juvenil, como moral, y estética. Síntomas todos ellos de una época, que cristalizan decantados en los procedimientos previamente analizados en relación a la vida y obra de Luis Buñuel, Salvador Dalí y Federico García Lorca.

\section{Bibliografía}

AlCALÁ, Manuel (1973). Buñuel (cine e ideología). Cuadernos para el Diálogo (EDICUSA). Madrid.

Aub, Max (1985). Conversaciones con Buñuel. Seguidas de 45 entrevistas con familiares, amigos y colaboradores del cineasta aragonés. Aguilar. Madrid.

Buñuel, Luis (1982). Mi último suspiro. Plaza \& Janes. Barcelona.

Corsi, Paulina (2002). "Aproximación preliminar al concepto de pulsión de muerte en Freud", en Revista Chilena de Neuro-psiquiatría (versión On-line), vol. 40, n. 4, pp. 361-370.

DALí, Salvador (1978). El mito trágico del "Ángelus” de Millet. Tusquets. Barcelona. DALí, Salvador (1983). Rostros ocultos. Plaza \& Janés. Barcelona. 
DALí, Salvador (2003). Textos autobiográficos (las pasiones según Dali; Confesiones inconfesables), 2. Fundació Gala-Salvador Dalí. Barcelona.

DALÍ, Salvador (2008). Metamorfosis de Narciso. Fundació Gala-Salvador Dalí. Galaxia Gutenberg. Círculo de Lectores. Barcelona.

Deleuze, Gilles (1984). La imagen-movimiento. Estudios sobre cine 1. Paidós. Barcelona.

Evans, Peter William (1998). Las películas de Luis Buñuel. La subjetividad y el deseo. Comunicación cine, 96. Paidós. Barcelona.

Freud, Sigmund (1966). Esquema del psicoanálisis. Paidós. Buenos Aires.

Freud, Sigmund (2002). Tres ensayos sobre teoría sexual. EL PAIS, Editorial Biblioteca Nueva. Madrid.

Freud, Sigmund (2003). Ensayos sobre la vida sexual y la teoría de la neurosis. Biblioteca Freud, Alianza. Madrid.

Freud, Sigmund (2003). Psicología de las masas; Más allá del principio del placer; El porvenir de una ilusión. Biblioteca Freud, Alianza. Madrid.

Fuentes Barco, Marina, Martínez Alonso, Belén, Piñeiro García, Sergio, y Angosto SAURA, Tiburcio (2008). "Biografía de Sabina Spielrein (1885-1942): Una historia de los primeros años del psicoanálisis", en Revista de la Asociación Española de Neuropsiquiatría, vol. XXVIII, no 101, pp. 109-117.

García Gállego, Jesús (comp.) (1987). Surrealismo: el ojo soluble. Litoral. Torremolinos (Málaga).

García Lorca, Federico (2008). Obra completa II. Poesía, 2. Obra completa III. Teatro, 1. Obra completa V. Teatro, 3. Cine. Música. Akal. Madrid.

Gibson, Ian (1998). Vida, pasión y muerte de Federico García Lorca (1898-1936). Plaza \& Janés. Barcelona.

Gibson, Ian (2000). Lorca-Dalí. El amor que no pudo ser. Plaza \& Janés. Barcelona.

Gibson, Ian (2010). Lorca y el mundo gay. Caballo azul de mi locura. Planeta. Barcelona.

IriBAs Rudín, Ana (2004). "Salvador Dalí desde el psicoanálisis", en Arte, individuo y sociedad, vol. 16, pp. 19-47.

KerR, John (1995). La historia secreta del psicoanálisis. Jung, Freud y Sabina Spielrein. Crítica. Grijalbo Mondadori. Barcelona.

LARA, Antonio (1982). "El amor y el cine", en Revista de Occidente, $\mathrm{n}^{\text {os }}$ 15-16 (Extraordinario III: sobre el amor), pp. 175-185.

LÁzaro Docio, Jesús (2010). El secreto creador de Salvador Dalí. El método paranoico-crítico (1927-1937). Eutelequia, Madrid.

Poyato Sánchez, Pedro (2011). El sistema estético de Luis Buñuel. Comunicación. Universidad el País Vasco. Bilbao.

Ramírez, Juan Antonio (2002). Dalí: lo crudo y lo podrido. La Balsa de Medusa, 124. Antonio Machado Libros. Madrid. 
SÁnCHEZ Vidal, Agustín (1991). Luis Buñuel. Signo e Imagen/Cineastas. Cátedra. Madrid.

SÁnChEZ Vidal, Agustín (2009). Buñuel, Lorca, Dalí: El enigma sin fin. Planeta. Barcelona.

Santos Torroella, Rafael (1984). La miel es más dulce que la sangre: las épocas lorquiana y freudiana de Salvador Dalí. Seix Barral. Madrid.

SkeA, Brian R. (2006). "Sabina Spielrein: out from the shadow of Jung and Freud", en Journal of Analytical Psychology, vol. 51, pp. 527-552.

Vallejo Orellana, Reyes y Sánchez-Barranco Ruiz, Antonio (2003). "Sabina Spielrein, la primera mujer que enriqueció la teoría psicoanalítica", en Revista de la Asociación Española de Neuropsiquiatría, vol. XXII, nº. 85, pp. 107-122.

WAelder, Robert (2005). El sexo de Freud. Losada. Madrid. 